\title{
DEMOKRATISASI OTONOMI DAERAH SEBAGAI WUJUD REFORMASI BUDAYA
}

\author{
Mat Jalil \\ STAIN Jurai Siwo Metro
}

\begin{abstract}
The essential of Pancasila Democracy teaches the openness. The openness is a condition to make democracy has function, citizen politic participation would not exist without the openness. Regional autonomy is regional authority to arrange, and manage the interest of local people according to its initiative. Regional autonomy gives a wide chance to the people to be participated in their regional management in order to create collective prosperity. Tha active participation of people to the democratic economy development process by means of togetherness which is has mutual benefit as the participation process from, by, and to the people. Autonomy covered the competence to discuss, consider, choose, and do different act inside the private or public to achieve democracy or public beneficience.

The connection between the regional as a fair framework, and the people as the agents who can determine. The connection between village as a independent law institution or based structure of law, the institutions, and the idea about democracy as a autonomous determiner. The characteristic of democracy connection and regional autonomy are political thoughts, where focusing region as a powerful position in the society.

Keywords: democracy, autonomy, openness, transperancy.
\end{abstract}

\section{PENDAHULUAN}

Memperhatikan alam Indonesia dimasa lalu hingga kini demokrasi diwarnai peraturan-peratutan autokrasi dan feodalisme yang dilakukan oleh pemerintahan raja-raja dan penjajah menyebabkan rakyat Indonesia semakin tertindas. Realitas kehidupan bermasyarakat dan bernegara di Indonesia tidak selamanya konsep demokrasi dapat diterapkan menurut teori-teori yang telah ada, keadaan ini dapat dilihat pada realitas pemerintahan Orde Lama dengan pemerintahan terpimpin, Orde Baru dalam pemerintahan militeristik, di era reformasi gejala anarkis semakin menonjol, penyelesaian konflik dengan kekerasaan telah menjadi model politik dan seolah-olah telah melembaga dalam kehidupan bermasyarakat, fenomena ini merupakan suatu realitas politik yang tidak relevan dengan demokrasi.

Perubahan kultur politik sentralisasi menjadi desentralisasi dengan penguatan otonomi daerah menjadi tidak bermakna, manakala reformasi politik, hukum dan ekonomi tidak dibarengi 
dengan reformasi budaya agar masyarakat terbebas dari belenggu kesemuan yang telah menghilangkan daya kreatif dan daya kritisnya. Reformasi budaya merupakan perubahan budaya politik yang diarahkan pada pemahaman, penghayatan dan pengalaman atau perilaku bernegara dan bermasyarakat dengan menempatkan kedaulatan ada di tangan rakyat, demokrasi yang harus dilaksanakan secara bertangsgung jawab.

Syarat mutlak bagi demokrasi adalah memberikan perlakuan yang sama terhadap semua orang dihadapan hukum dan perlindungan para warga negara dari penggunaan otoritas politik dan kekuasaan memaksa yang sewenang-wenang ${ }^{1}$. Hal ini dibutuhkan untuk melindungi klaim-klaim terhadap hak, dan kebebasan, dimana suatu masyarakat yang diperintah dalam kerangka keadilan harus memberdayakan secara adil semua angotanya.

Gagasan demokrasi menyangkut ide tentang pengaturan diri yakni pandangan bahwa anggota komunitas politik, dan para warga negaranya seharusnya dapat memilih secara bebas kondisi perhimpunan mereka sendiri, dan pilihan mereka seyogyanya merupakan legitimasi bagi bentuk, dan arah politik mereka. Suatu kerangka kerja yang adil bagi pengaturan masyarakat adalah kerja yang dipilih dengan bebas.

Demokrasi sebagai otoritas tertinggi dan atau otoritas independen mendasari perbuatan keputusan yang benar dalam kerangka kerja nasional, karena kedaulatan sebagai otoritas politik dalam suatu komunitas yang mempunyai hak untuk diakui untuk melaksanakan kekuasaan negera untuk menentukan undangundang, peraturan dan kebijakan pada suatu wilayah. Adanya otonomi dalam menentukan kebijakan daerah dalam menentukan hubungan berskala nasional dan internasional. Otonomi daerah diselenggarakan bukan hanya atas kepentingan untuk melaksanakan desentralisasi kekuasaan dari pemerintah pusat ke daerah, bukan untuk kepentingan perimbangan keuangan pusat dan daerah. Otonomi daerah dimaksudkan untuk perbaikan di berbagai sektor, melalui desentralisasi kekuasaan dan kebijaksanaan serta perimbangan keuangan antara pusat dan daerah. Desentralisasi kekuasaan memungkinkan daerah untuk merancang upaya pembangunan sesuai dengan kebutuhannya sendiri, sedangkan perimbangan keuangan pusat dan daerah merupakan pertimbangan realistis sekaligus untuk memacu pertumbuhan pembangunan di

1 David Held, Demokrasi dan Tatanan Global, (Yogyakarta: Pustaka Pelajar Offset, 2004), h. 180. 
daerah dengan alokasi dana yang memadai untuk kepentingan daerah itu sendiri. Otonomi mengembangkan demokrasi langsung pada arus bawah dan menjamin pembangunan yang stabil di daerah $^{2}$. Masyarakat bawah mempunyai kewenangan menentukan dan menjamin keberlangsungan pembangunan di daerahnya.

Otonomi daerah adalah kewenangan daerah untuk mengatur dan mengurus kepentingan masyarakat setempat berdasarkan prakarsa sendiri sesuai dengan aspirasi dan peraturan perundangundangan yang berlaku. Kewenangan ini diberikan oleh pemerintah pusat diserahkan secara formal kepada pemerintah daerah, melalui kebijaksanaan desentralisasi (politik dan fiskal) dengan dikeluarkanya UU No 22 tahun 1999 tentang pemerintah daerah dan UU No 25 tahun 1999 tentang perimbangan keuangan pusat-daerah, sebagai landasan lahirnya otonomi daerah dan beralih dari sistem pemerintahan sentralisasi menjadi desentralisasi. Tujuan utama dari kebijaksanaan desentralisasi "Membebaskan pemerintah pusat dari beban-beban yang tidak perlu dalam menangani urusan domestik, sehingga pemerintah pusat berkesempatan untuk mempelajari, memahami, merespon berbagai kecendrungan global dan mengambil manfaat dari padanya. Pemerintah pusat diharapkan lebih mampu berkonsentrasi pada perumusan kebijakan makro nasional yang bersifat strategis.

\section{DEMOKRASI}

Watak dan ruang lingkup otoritas tertinggi negara-bangsa kontemporer dapat dipetakan dengan melihat pada sejumlah keterputusan internasional dan eksternal, antara wilayah otoritas politik formal yang diklaim bagi daerah sendiri dan di lain pihak struktur dan sistem negara dan sistem ekonomi pada tingkat daerah, nasional, regional dan global.

Indonesia merupakan negara demokrasi berlandaskan Pancasila yang berintikan pada sila keempat Kerakyatan yang dipimpin oleh hikmat kebijaksanaan dalam permusyawaratan/perwakilan. Kerakyatan berarti sesuainya dengan hakikat rakyat. Hakikat kerakyatan adalah bersatunya semua rakyat dalam suatu wilayah negara Indonesia. Hakikat rakyat sebagai suatu akibat bersatunya manusia sebagai makhluk Tuhan Yang Maha Esa dalam suatu wilayah negara tertentu ${ }^{3}$. Rakyat adalah seluruh manusia yang bertempat tinggal disuatu negara dan menjadi

2 Abdul Aziz dan David Arnold, Desentralisasi Pemerintahan Pengalaman Negara-negara Asia, (Yogyakarta: Pustaka Amanah, 2003), h. 95.

${ }^{3}$ Kaelan, Pendidikan Pancasila, (Yogyakarta: Paradigma, 2004), h. 66. 
pendukung dan unsur negara ${ }^{4}$. Kerakyatan menggambarkan bahwa negara Indonesia bukan negara untuk satu orang, atau satu golongan. Sila kerakyatan didasari dan dijiwai oleh sila Ketuhanan Yang Maha Esa, sila Kemanusiaan yang adil dan beradab dan sila Persatuan Indonesia. Sila kerakyatan juga mendasari sila Keadilan sosial bagi seluruh rakyat Indonesia, mengandung arti adanya negara demi kesejahteraan warganya, maka tujuan negara adalaah terwujudnya masyarakat yang berkeadilan.

Kekuasaan dalam demokrasi Pancasila harus mencerminkan komunitas, dimana pemimpin bertanggung jawab terhadap semua aspek pemerintah dan kesejahteraan ${ }^{5}$. Manusia Indonesia sebagai warga negara, dan warga masyarakat mempunyai kedudukan, hak, dan kewajiban yang sama dalam menggunakan hak-haknya, harus memperhatikan, dan mengutamakan kepentingan negara, dan kepentingan masyarakat ${ }^{6}$ Kedudukan, hak, dan kewajiban yang sama mengandung arti tidak boleh ada suatu kehendak yang dipaksakan kepada pihak lain. Keputusan yang menyangkut kepentingan orang banyak harus dimusyawarahkan untuk mufakat diliputi semangat kekeluargaan yang merupakan ciri khas demokrasi Indonesia.

Hak-hak rakyat mendapat jaminan sebagaimana diungkapkan pasal 28 UUD 1945 Kemerdekaan berserikat dan berkumpul, mengeluarkan pikiran dengan lisan atau tulisan. Pasal 28 UUD 1945 memberikan dasar keterbukaan dan kebebasan bagi warga negara. Hakikat demokrasi Pancasila yang mengajarkan adanya keterbukaan. Keterbukaan adalah suatu kondisi untuk memungkinkan demokrasi berfungsi, patisipasi politik rakyat tidak akan ada tampa adanya keterbukaan. Keterbukaan bisa berjalan optimal hanya dalam iklim dan lingkungan yang demokratis?. Keterbukaan atau transparasi menjadi kata kunci dalam kehidupan politik yang demokratis, maka nilai-nilai dasar kehidupan politik yang demokratis harus dilaksanakan. Demokrasi Indonesia tidak dapat dipisahkan dari alur periodisasi sejarah politik di Indonesia yakni apa yang disebut sebagai periode pemerintahan masa revolusi kemerdekaan, pemerintahan parlemen, pemerintahan demokrasi terpimpin, pemerintahan Orde Baru dan pemerintahan reformasi.

4 Sunoto, Filsafat Pancasila, (Yogyakarta: Prasetya Pratama, 1992), h. 66.

5 David Bourehier, Pancasila Versi Orde Baru, (Yogyakarta: Pusat Studi Pancasila UGM Bekerjasama dengan Pusat Studi Sosial Asia tenggara UGM dan Perhimpunan Pendidikaan demokrasi Asia Tenggara, 2007), h. 260.

6 Soejadi, Pancasila Sebagai Sumber Tatatertib Hukum Indonesia, (Yogyakarta: Lukman Ofset, 1999), h. 96.

7 Maulani, Demokrasi dan Pembangunan Derah, (Yogyakarta: CRDS Kalimantan Bekerjasama Pustaka Pelajar, 2000), h. 60. 
Pengalaman sebagai rakyat jajahan dengan pemerintahan autokrasi kolonial mendorong rakyat Indonesia kepada cita-cita negara hukum yang demokratis. Kedaulatan harus berdasarkan kedaulatan rakyat, kedaulatan rakyat berbeda dengan kedaulatan liberalisme, sosialis dan pluralisme. Para penyelenggara negara awal periode kemerdekaan yakin bahwa demokrasi bukan merupakan sesuatu yang terbatas pada komitmen tetapi juga merupakan sesuatu yang perlu diwujudkan ${ }^{8}$. Kedaulatan Indonesia berakar pada pengalaman hidup sehari-hari yang bercorak kolektivisme. Demokrasi Indonesia berdasarkan demokrasi asli yang berlaku di dalam desa Indonesia yaitu cita-cita perjuangan dan terlaksananya dasar-dasar perikemanusiaan dan keadilan sosial “Demokrasi politik tidak dapat melaksanakan persamaan dan persaudaraan, karenanya demokrasi politik harus pula berlaku demokrasi ekonomi ${ }^{9}$. Cita-cita demokrasi Indonesia adalah demokrasi sosial meliputi seluruh lingkungan hidup yang menentukan nasib manusia.

Kehidupan masyarakat nusantara dikenal adanya kelompokkelompok masyarakat yang disebut kaum, tiap-tiap warga kaum dianggap mempunyai hak dan kedudukan yang sama, sedangkan kepala kaum tidak mempunyai kelebihan hak atas warga lainnya. Kemerdekaan, persamaan, dan persaudaraan merupakan dasar-dasar pokok kelangsungan kaum dan menjadi tabiat dasar dari kerakyatan dalam persekutuan kaum pada masyarakat ${ }^{10}$. Di dalam pergaulan masyarakat kaum tidak membedakan satu dengan anggota kaum yang lain, kehidupan masyarakat kaum nusantara yang bersifat kolektif menjadi sumber demokrasi Indonesia. Tiga sumber demokrasi Indonesia yaitu:

1. Paham sosialis Barat sebagai dasar perikemanusiaan

2. Ajaran Islam yang menuntut keadilan Illahi dalam masyarakat serta persaudaraan antara manusia sebagai makhluk Tuhan, sesuai dengan sifat Allah Yang Maha Pengasih dan Penyayang.

3. Pengetahuan bahwa masyarakat Indonesia bardasarkan kolektivisme ${ }^{11}$.

Demokrasi asli Indonesia memiliki anasir: rapat, mufakat, gotong royong, hak mengadakan protes bersama dan hak untuk

8 Afan Gaffar, Politik Indonesia Transisi Menuju Demokrasi, (Yogyakarta: Pustaka Pelajar Offset, 2006), h. 10.

9 Sri Edi Swasono, Muhammad Hatta: Beberapa Pokok Pikiran, (Jakarta: Yayasan Hatta, , 1992), h. 121.

10 Moh. Mahfud MD, Dasar dan Struktur Ketatanegaraan Indonesia, (Jakarta: Renetika Cipta, 2001), h. 31.

11 Ibid, h. 121. 
menyingkir dari daerah kekuasaan raja12. Demokrasi Indonesia memerlukan suatu persyaratan khusus yakni dilepasnya bias dan etnosentrisme karena hal itu membuat rakyat tidak mampu menatap diri dengan objektif. Partisipasi politik rakyat adalah mewujudkan kultur demokrasi. Teori demokrasi dalam pemerintahan sering didengar, namun dalam realisasinya mengalami beberapa hambatan. Menurut Christina ada empat sebab mengapa demokratisasi di Indonesia mengalami kemacetan:

Pertama, Pasal 1 UUD RI disebutkan "Kedaulatan ada ditangan rakyat dan dijalankan sepenuhnya oleh MPR" hal ini menggambarkan bahwa rakyat tidak bisa secara langsung memerintah, tetapi menggunakan sistem perwakilan, dalam hal ini yang mewakili adalah MPR. Masalahnya, orang yang diwakili dengan orang yang mewakili mempunyai suatu jarak, ini dapat dilihat wakil yang duduk dalam lembaga MPR kadang-kadang tidak saling mengenal dan banyak juga yang ternyata tidak mengenali daerah yang diwakilinya. Kedua, unsur-unsur keterwakilan, masih banyak yang mempertanyakan tentang keterwakilan dalam lembaga ini (MPR) apakah seharusnya berasal dari agama atau ras atau berasal dari suku, dan sebagainya, itu mempunyai kekurangan dan kelebihannya sendiri. Ketiga, Banyak anggota perwakilan yang tidak mempunyai pengalaman. Keempat, dalam pemerintahan demokrasi, titik permasalahan bukan sekadar soal asal legitimasi kekuasaan, melainkan juga soal bagaimana kekuasaan itu diselenggarakan. ${ }^{13}$

Kewenangan yang diberikan kepada penguasa sudah tentu bukan merupakan kepasrahan buta, melainkan hanya sebagian kewenangan, sebagian lagi masih berada ditangan rakyat. Kondisi dan persoalan yang demikian memerlukan pemikiran mendasar tentang dasar-dasar demokrasi di Indonesia melalui filsafat politik atau pemikiran politik dapat mendefinisikan ulang konsep dan praktik politik seperti konsep demokrasi, kekuasaan, otoritas, peran hukum, aspek keadilan.

\section{DEMOKRASI DAN OTONOMI DAERAH}

Demokrasi adalah pemerintahan oleh rakyat yakni penentuan pembuatan keputusan publik oleh anggota-anggota komunitas politik yang sama-sama bebas, maka pembenarannya terletak pada kemajuan, dan peningkatan otonomi, baik sebagai individu, sebagai warga negara maupun bagi kolektivitas ${ }^{14}$. Peningkatan otonomi pada masyarakat terlihat pada tradisi Yunani Kuno dimana tugas pokok menyiapkan hukum dan merencanakan kebijaksanaan publik

12 Ibid, h. 123.

13 Nico Kana, Dinamika Politik Lokal di Indonesia, (Salatiga: Pustaka Percik Salatiga, 2001), h. 260.

14 David Held, Demokrasi, h. 181. 
dipercayakan kepada organ pemerintahan yang kecil disebut konsul15. Prinsip otonomi adalah orang seharusnya menikmati hak yang sama, dan karena itu kewajiban yang sama dalam penetapan kerangka kerja politik yang menghasilkan, dan membatasi kesempatan yang tersedia buat mereka, yakni mereka seharusnya bebas, dan sama dalam menentukan kondisi kehidupan mereka sendiri, sepanjang mereka tidak menyebarkan kerangka kerja ini untuk meniadakan hak orang lain ${ }^{16}$. Otonomi mengandung pengertian kemampuan manusia untuk melakukan pertimbangan secara sadar diri, melakukan perenungan diri dan melakukan penentuan diri. Otonomi mencakup kemampuan untuk berunding, mempertimbangkan, memilih dan melakukan tindakan yang berbeda baik dalam kehidupan pribadi maupun kehidupan publik untuk mencapai demokrasi atau kebaikan umum. Pembangunan yang demokratis merupakan pembangunan nasional yang berdasarkan aspirasi masyarakat, oleh masyarakat dan untuk kepentingan masyarakat ${ }^{17}$. Melalui peran serta masyarakat dalam pembangunan akan memunculkan sikap keterbukaan dan fleksibilitas sistem politik dan kelembagaan sosial, sehingga mempermudah proses pembangunan.

Prinsip otonomi secara esensial mengungkapkan dua gagasan pokok yakni gagasan bahwa rakyat seharusnya memegang peranan penentuan diri, dan gagasan bahwa pemerintahan demokratis harus menjadi pemerintahan yang terbatas pemerintahan, menjunjung tinggi struktur kekuasaan yang dibatasi secara resmi ${ }^{18}$. John Rawls menyebutkan kedudukan dan alasan prinsip otonomi adalah politis yaitu gagasan-gagasan pokok teori politik yang bisa dipertahankan dapat diperoleh dari gagasan intuitif yang tertanam dalam budaya politik publik dalam suatu konsensus yang saling melengkapi yang mencakup ajaran filsafat moral dan agama ${ }^{19}$. Prinsip ini membentuk struktur dalam atau kerangka kerja gagasan yang dapat disebarkan untuk membentuk susunan, dan menyusun kembali masalahmasalah publik, tugas teori politik adalah untuk menerangkan, dan menganalisis intuisi-intuisi, dan konsep-konsep dasar persetujuan. Jadi prinsip otonom dapat dipahami dalam suatu pengertian yang melekat dalam budaya politik suatu masyarakat yang demokratis.

\footnotetext{
15 Herry Scmandt, Filsafat Politik, (Yogyakarta: Pustaka Pelajar, 2002), h. 40.

16 David Held, Demokrasi, h. 182.

17 Mardiasmo, Otonomi \& Manajemen Keuangan Daerah, (Yogyakarta: Andi, 2004) h. 65.

18 David Held, Demokrasi, h. 182.

19 John Raws, Teori Keadilan: Dasar-dasar Filsafat Politik untuk Mewujudkan Kesejahteraan Sosial dalam Negara, (Yogyakarta: Pustaka Pelajar, 2006), h. 10.
} 
Berkaitan dengan otonomi daerah, hubungan antara daerah sebagai suatu kerangka kerja yang adil, dan rakyat sebagai agen-agen yang menentukan. Hubungan desa sebagai suatu badan hukum independen atau struktur dasar hukum, institusi-institusi, dan gagasan mengenai demokrasi sebagai penentu yang otonom. Sifat hubungan demokrasi, dan otonomi daerah merupakan wilayah dalam pemikiran politik, dimana menempatkan daerah sebagai suatu posisi yang sangat kuat dalam kaitannya dengan masyarakat.

Otonomi daerah adalah kewenangan daerah untuk mengatur, dan mengurus kepentingan masyarakat setempat berdasarkan prakarsanya sendiri sesuai dengan aspirasi dan peraturan perundang-undangan yang berlaku ${ }^{20}$. Di dalam ketentuan umum Bab I Undang-undang Otonomi daerah dijelaskan pengertian otonomi daerah adalah hak wewenang, dan kewajiban daerah otonomi untuk mengatur, dan mengurus sendiri urusan pemerintahan, dan kepentingan masyarakat setempat sesuai dengan peraturan perundang-undangan. Pemerintah daerah mendapat kewenangan dari pemerintah pusat untuk menyelenggarakan pemerintahan berdasarkan UU nomor 22 tahun 1999 tentang pemerintahan daerah ${ }^{21}$ yang sudah direvisi menjadi UU Nomor 32 tahun 2004.

Penyerahan wewenang berarti memberikan keluasan untuk mengatur rumah tangganya sendiri. Inti pelaksanaan otonomi daerah adalah keluasan pemerintah daerah untuk menyelenggarakan pemerintahan sendiri atas dasar prakarsa kreaktivitas dan peran serta aktif masyarakat dalam rangka mengembangkan, dan memajukan daerahnya masing-masing 22 . Otonomi daerah memberikan peluang yang luas bagi masyarakat untuk berpartisipasi dalam wujud pengelolaan daerahnya untuk kemakmuran bersama. Peran serta aktif masyarakat dalam proses pembangunan ekonomi yang lebih demokratis melalui penerapan nyata kebersamaan yang saling menguntungkan sebagai perwujudan proses dari, oleh, dan untuk rakyat ${ }^{23}$. Partisipasi aktif dari warga masyarakat dalam wilayah otonomi artinya rakyat ikut diberdayakan dalam mengelola daerahnya masing-masing.

Daerah otonomi adalah kesatuan masyarakat hukum yang mempunyai batas-batas wilayah yang berwenang mengatur, dan mengurus urusan pemerintahan, dan kepentingan masyarakat setempat menurut prakarsa sendiri berdasarkan aspirasi masyarakat

20 Said Ruhpina, Menuju Demokrasi Pemerintahan, (Mataram: Universitas Mataram Pers, 2005), h. 3.

${ }^{21}$ Anonim, Undang-undang Otonomi Daerah 2009, h. 11.

$22 \mathrm{Ibid}$, h. 4.

${ }^{23}$ Mardiasmo, Otonomi, h. 65. 
dalam sistem Negara Kesatuan Republik Indonesia (Undang-undang Otonomi daerah). Otonomi daerah merupakan bentuk pemerintahan di dalam negeri mendapatkan otonomi bermacam-macam sesuai dengan keberagaman, dan potensi dearah yang ada, sehingga masing-masing daerah dapat mencari program keunggulan sebagai andalan. Sedangkan dalam urusan keluar daerah-daerah yang bersifat internasional (global) tetap dalam kerangka kesatuan yakni Republik Indonesia.

Maksud diadakan otonomi daerah adalah dalam rangka mencegah terjadinya kembali sentralisasi kekuasaan, menumbuhkan demokrasi dari bawah, efesiensi, dan efektifitas pemerintahan, pengakuan terhadap keragaman potensi alam, dan sosial budaya daerah serta pemerataan pembangunan ekonomi yang memberikan keadilan pada masyarakat di daerah ${ }^{24}$. Memasuki otonomi daerah berarti masuk dalam ranah desentralisasi dan tujuan utama desentralisasi adalah:

1. Membebaskan pemerintah pusat dari beban-beban yang tidak perlu dalam menangani urusan domestik, sehingga pemerintah pusat berkesempatan untuk mempelajari, memahami, merespon berbagai kecendrungan global dan mengambil manfaat dari padanya.

2. Pemerintah pusat diharapkan lebih mampu berkonsentrasi pada perumusan kebijakan makro nasional yang bersifat strategis.

3. Kewenangan pemerintah ke daerah, maka daerah akan mengalami proses pemberdayaan yang signifikan. Kemampuan prakarsa dan kreaktivitas mereka akan terpacu, sehingga kapabilitas dalam mengatasi berbagai masalah domestik akan semakin kuat ${ }^{25}$.

Ciri utama otonomi daerah adalah adanya lembaga perwakilan daerah dan eksekutif yang berfungsi sebagai lembaga politik lokal. Mereka yang berkiprah dengan politik di tingkat lokal dalam kehidupan sehari-hari, tentu akan lebih memahami dinamika sosial yang terjadi. Pemerintahan lokal yang demokratis mempunyai konsekuensi Dewan Perwakilan Rakyat Daerah (DPRD) menjadi aktor utama penentu kebijakan.

Prinsip otonomi daerah berada pada inti proyek demokrasi, yakni suatu proyek yang didistribusikan dengan kemampuan orang untuk menentukan dan membenarkan tindakan mereka sendiri,

\footnotetext{
24 Anonim, Undang-undang, h. 4.

25 Afan Gaffar, Politik, h. 8.
} 
dengan kemampuan mereka untuk memilih di antara programprogram politik alternatif, tradisi demokrasi partisipasi menjunjung tinggi gagasan yang berada di pusat prinsip otonomi.

Partisipasi di dalam demokrasi merupakan hal yang paling mutlak $^{26}$. Gagasan-gagasan terlihat pada gerakan-gerakan politik, dan tradisi-tradisi intlektual yang berusaha meletakan pemerintahan demokratis, sebagai perjuangan hak bagi warganegara. Partisipasi rakyat secara efektif dibutuhkan dua syarat penting yakni pertama, adanya kebebasan untuk memperoleh akses kepada informasi, menyampaikan pendapat, dan berorganisasi, kedua, adanya kesediaan berbagi kekuasaan dengan kelompok-kelompok lain ${ }^{27}$. Keterbukaan masyarakat, dan akses informasi merupakan kondisi untuk memungkinkan partisipasi rakyat.

Partisipasi membutuhkan adanya ruang politik yang terbuka dan terjamin kesamaannya ${ }^{28}$. Hak kewarganegaraan membentuk pemahaman lingkungan tindakan independen yang sah, hak ikut terlibat dalam perjuangan otonomi daerah, dimulai dari tempat dimana warga negara di lahirkan, dan dari pekerjaan yang ditentukan, perjuangan akhirnya melibatkan kemerdekaan berbicara, berekpresi, kepercayaan, dan perhimpunan, kemerdekaan bagi wanita, pemungutan suara yang bebas, dan jujur ${ }^{29}$. Otonomi warga negara dapat dipresentasikan dengan hak-hak yang bisa dinikmati oleh rakyat sebagai hasil dari status warga negara sebagai anggota yang bebas, dan sederajat dari komunitas. Persolan-persolan otonomi daerah meliputi:

a. Poros pemikiran, dan penyelenggaraan pemerintahan lokal ada ditingkat Kabupaten/Kota, dan untuk menjangkau langsung masyarakatnya perlu ditopang dengan pengembangan sistem penyelenggaraan pemerintahan di tingkat desa.

b. Perlunya suatu sistem pengambilan kebijakan publik yang disatu sisi memungkinkan partisipasi secara optimal dan disisi lain menghasilkan stabilitas sistematik.

c. Sistem penyelenggaraan pemerintahan perlu dibangun di atas prinsip kesepadanaan. Untuk itu, maka institusi lokal yang asli yang masih fungsional harus menjadi acuannya ${ }^{30}$.

\footnotetext{
${ }^{26}$ Nico Kana, Dinamika, h. 261.

27 Maulani, Demokrasi, h. 54.

28 Nico Kana, Dinamika, h. 263.

${ }^{29}$ David Held, Demokrasi, h. 185.

30 Edi Santoso, Merubah Watak Negara: Strategi Penguatan Partisipasi Desa,
} (ttp: Lappera Pustaka, 2004), h. 17. 
Gagasan demokrasi menghubungkan otonomi aspirasi yang beraneka ragam, melakukan pertimbangan, perenungan, dan pertimbangan secara sadar diri, otonomi daerah mencakup kemampuan untuk bertindak. Kemampuan ini dituangkan melalui demokrasi yang menegaskan bahwa hanya melalui institusi-institusi pemerintahan perwakilan domokratislah komitmen otonomi dapat dijunjung tingggi.

Memahami prinsip otonomi dalam hubungannya dengan demokrasi dapat dijelaskan sebagai berikut:

1. Prinsip otonomi berusaha mengartikulasikan dasar yang dapat menjadi pijakan untuk mengabsahkan kekuasaan politik, dipandang sebagai prinsip legitimasi politik.

2. Pandangan bahwa orang-orang seharusnya menikmati hak-hak dan kewajiban-kewajiban yang sama dalam kerangka kerja politik yang membentuk kehidupan dan kesempatan-kesempatan mereka ini berarti mereka menikmati struktur tindakan politik bersama, agar mereka mengejar proyek-proyek mereka baik individual maupun kolektif, sebagai agen-agen yang bebas dan netral.

3. Konsep hak-hak mengandung pengertian dalam suatu pemberian hak untuk mencari tindakan dan kegiatan tampa campur tangan sewenang-wenang atau tidak adil.

4. Hak-hak dan kewajiban khusus yang dibatasi oleh prinsip otonomi adalah hak dan kewajiban-kewajiban yang perlu untuk melindungi suatu kepentingan yang pada prinsipnya sama.

5. Gagasan bahwa rakyat seharusnya bebas, dan sederajat dalam menentukan kondisi-kondisi kehidupan mereka sendiri berarti bahwa mereka seharusnya bisa berpartisipasi dalam proses perundingan yang terbuka bagi semua atas dasar kebebasan dan persamaan, mengenai masalah-masalah umum.

6. Hak-hak seseorang memerlukan perlindungan yang jelas, prinsip otonomi menentukan secara bersamaan bahwa rakyat harus bebas dan sederajat dan mayoritas seharusnya tidak bisa membebankan diri mereka secara sewenang wenang kepada orang lain ${ }^{31}$.

Otonomi daerah hendaknya di mulai dari tingkat desa, dimana desa adalah unit penyelenggaraan pemerintahan yang paling kecil dan sangat mungkin terbuka untuk mewujududkan demokrasi langsung. Wacana pengembangan demokrasi desa terkandung dalam Undang-undang No 22 Tahun 1999 tentang Pemerintahan Daerah yang mensyaratkan dibentuknya lembaga perwakilan rakyat yakni

31 David Held, Demokrasi, h. 189. 
Perwakilan Desa (BPD) sosok demokrasi yang dikembangkan di desa harus didudukkan dalam sistem penyelenggaraan pemerintahan dalam lingkungan yang lebih luas, sehingga masyarakat memperoleh kedemokrasiannya dalam mengembangkan daerahnya.

Demokrasi mensyaratkan adanya warga negara yang memiliki otonomi, dalam demokrasi otonomi menjadi penting bukan hanya bagi pemerintahan daerah itu sendiri. Tidak adanya otonomi warga negara akan menstruktur peluang bagi pemerintah untuk tidak hirau terhadap rakyatnya ${ }^{32}$. Oleh karenanya agenda pengembangan otonomi daerah perlu dimaknai sebagai kesatuan agenda dalam pengembangan sistem pengambilan kebijaksanaan yang demokratis.

Otonomi daerah dibutuhkan dalam rangka membangun akses (access) daerah untuk mempengaruhi pengambilan keputusan di tingkat pusat, hal ini penting untuk dibangun kerena hampir setiap saat terdapat kebijakan-kebijakan pusat yang mempengaruhi sendisendi kehidupan di daerah. Otonomi daerah adalah penyaluran aspirasi daerah dirumuskan dari proses demokrasi lokal. Akses daerah dalam pemerintahan nasional ini bisa dibangun melalui pembangunan lembaga-lembaga supra struktur politik seperti pembentukan Dewan Perwakilan Daerah.

Kebijakan otonomi daerah merupakan upaya pemberdayaan daerah, maka kepentingan daerah harus menjadi prioritas utama. Daerah menjadi prioritas setiap proyek pembangunan nasional, serta masyarakat menjadi terlibat secara aktif dalam setiap perencanaan hingga pelaksanaan, dan evaluasi kegiatan-kegiatan yang berhubungan dengan daerah sendiri, selain itu daerah diharapkan mampu melakukan terobosan-terobosan inovatif untuk mengembangkan dan mamajukan dirinya sendiri, sehingga daerahnya sebanding dan dapat sejajar dengan percaturan nasional dan internasional

Adanya otonomi daerah, daerah diberi kewenangan membuat keputusan, diserahkan kepada legeslatif daerah (DPRD) terutama yang menyangkut kepentingan umum dalam kontek kewenangan otonomi daerah seharusnya dipahami secara fungsional bukan secara kewilayahan, artinya orentasi otonomi daerah dalam upaya pemaksimalan pelaksanaan fungsi pemerintahan, dalam hal pelayanan, pengaturan dan pemberdayaan yang dapat dilakukan secepat, sedekat dan setepat mungkin dengan kebutuhan masyarakat. 
Otonomi daerah membutuhkan kerja sama sebagai sebuah kelompok kepentingan, kerjasama antar daerah sebagai jembatan demokrasi untuk memperjuangkan kepentingan bersama dalam menghadapi konflik-konflik antar daerah yang secara geografis cendrung mempunyai potensi komflik yang tinggi dan sekligus mempunyai kepentingan bersama. Melalui adanya kerjasama, daerah bisa melakukan negosiasi. Kerjasama dapat dilandasi atas dasar permasalahan yang serupa seperti daerah yang berpotensi konflik sosial dan kekerasan serta daerah yang rawan longsor, kebakaran hutan, kerjasama daerah dapat dilakukan bersifat temporer. Melalui otonomi daerah akan melatih para warga negara dalam demokrasi, dan mempercepat jalur pembangunan pedesaan dan memelihara stabilitas politik ${ }^{33}$.

Otonomi daerah berarti demokratisasi pemerintahan daerah dapat terwujud melalui desentralisasi berarti memindahkan kewenangan atau arena pemerintahan dari pusat ke daerah atau memindahkan sebagian urusan dari pusat ke daerah. Desentaralisasi mempunyai dua kelompok tujuan yakni politik dan administrasi. Tujuan politiknya adalah dalam rangka demokratisasi, dan tujuan administrasinya adalah dalam rangka efektifitas dan efesiensi. Sedangkan demokratisasi adalah proses perubahan dari struktur dan tatanan pemerintahan yang otoriter ke arah struktur dan tatanan demokratis. Demokrasi meningkatkan akses masyarakat dalam proses politik untuk jalannya pemerintahn di daerah. Demokratisasi merupakan proses dilakukannya diversifikasi kekuasaan untuk meniadakan kesenjangan hak-hak politik warga negara serta memperluas hak warga negara untuk bersuara dan berpendapat. Prinsip demokratisasi setiap keputusan harus dibicarakan bersama dan pelaksanaan atas keputusan itu di desentralisasikan menjadi elemen penting.

Perwujudan demokratisasi Indonesia dapat diwujudkan sebagai berikut:

1. Dilakukannya rasionalisasi kekuasaan yang melingkupi ruang lingkup kekuasaan serta waktu kekuasaannya seseorang dalam tampuk pemerintahan.

2. Adanya diffrensiasi konflik, dimana wilayah konflik dibatasi sehingga tidak semua konflik yang muncul dalam masyarakat langsung kepusat syaraf politik nasional.

33 Hans Antlov, Negara dalam Desa Patronase Kepemimpinan Lokal, (Yogyakarta: Garasi, 2003), h. 17. 
3. Peningkatan peran politik rakyat, agar kesadaran elit terpelihara bahwa mereka berkuasa karena diberi kewenangan, dianggap mampu, dan mau mengurus kepentingan rakyatnya.

4. Menghapus akar tegaknya rejim yang otoriter yang bertumpu kepada penggunaan represi fisik, dan ideologis untuk mendapatkan ketaatan warga negara, klientalkisme ekonomi untuk menguatkan basis legitimasi yang positif dan renumeratif, serta korporatoisme negara untuk menjamin informasi yang masuk ke dalam sistem politik tidak membuat sistem terkontaminasi oleh ide-ide pembaharuan ${ }^{34}$.

Prinsip-prinsip otonomi daerah yang dianut oleh UU No 22/1999 mencakup prinsip demokrasi, peran serta masyarakat, pemerataan dan keadilan serta potensi, dan keragaman daerah. Prinsip ini memberikan usaha dalam upaya membangun struktur dan mekanisme kerja sistem politik yang berdasarkan atas nilai-nilai dasar demokratis. Di lain pihak otonomi memberikan kesempatan peran serta masyarakat untuk berpartisipasi dalam pembangunan daerahnya, serta dapat memunculkan potensi daerahnya untuk digali demi keadilan dan pemerataan kesejahteraan. Undang-undang No 22/1999, mengandung semangat untuk memberikan keluasan bagi pemerintah daerah untuk menyelenggarakan pemerintahan sendiri atas dasar prakarsa, kreaktivitas dan peran aktif masyarakat dalam mengembangkan dan memajukan daerahnya.

Penyelenggaraan otonomi daerah dipandang perlu untuk lebih menekankan pada prinsip-prinsip demokrasi, peran serta masyarakat, pemerataan keadilan, serta memperhatikan potensi, dan keanekaragaman daerah ${ }^{35}$. Otonomi dimaknai sebagai kesediaan elite desa, baik formal, dan nonformal untuk mengembangkan proses dialogis kritis yang dapat memunculkan manfaat sosial bagi masyarakat. Para elite lokal diharapkan mampu untuk mengakumulasi sumber-sumber daya politik yang meliputi: Pertama, keterampilan dalam menafsirkan ulang berbagai kebijaksanaan yang dihasilkan oleh pemerintah pusat. Kedua, adanya penguasaan dan pemahaman atas problem yang dimiliki oleh daerah. Ketiga, adanya pola aliansi informasi antara sesama elite di daerah dengan pihak elit di pusat. Kesededian elite desa dimaksudkan untuk memberikan demokratisasi masyarakat desa dalam menghadapi dinamika politik

34Rasyid Sumanang, Bung Hatta Mengabdi pada Cita-cita Pembangunan Bangsa, (Jakarta: Penerbit Panitia Peringatan Ulang Tahun Bung Hatta ke 70, 1972), h. 119.

35 Abuya Busyro Karim, Indonesia Glonalisasi Otonomi Daerah, (Jakarta: Pilar, 2005), h. 9. 
lokal yang berkembang begitu pesat sejak dibukanya kran otonomi, hal ini dapat dilihat dari realita yang ada pada masyarakat Indonesia.

Pemerintahan daerah pada dasarnya upaya untuk mengantisipasi tuntutan perubahan zaman serta konsep, dan teori yang bersifat mondial dengan tetap memperhatikan aspek yuridis, politis, historis serta sosiologis setempat. Pemerintah dearah mencakup pemerintahan desa, dan desa adalah unit penyelenggaraan pemerintahan yang paling kecil dan justru unitnya yang kecil ini maka secara teoritis terbuka untuk mewujudkan gagasan demokrasi langsung. Demokrasi langsung sifatnya lebih partisipatif dan lebih inklusif dari pada demokrasi perwakilan, jelasnya lembaga perwakilan rakyat dikembangkan untuk mengatasi persoalan jumlah penduduk dan cakupan tritorial yang sangat luas khususnya pemberian otonomi daerah.

Pemerintahan desa selama ini banyak ditempa dan dibingkai oleh proses-proses, intraksi-intraksi, dan pembakuan-pembakuan yang terjadi dalam lingkup yang lebih luas dan unit yang paling bersingungan dengan rakyat, justru menduduki posisi paling rendah dalam struktur pengambilan kebijaksanaan. Hal ini dapat di lihat pada nasib desa yang selama ini banyak ditentukan oleh mereka yang tidak berada, dan tidak memahami kondisi riil di desa upaya mengembangkan demokrasi di desa justru terkekang dan terbimbing oleh pembakuan-pembakuan tingkat provinsi dan pusat, walaupun UUD 1945 memberikan perlindungan dan jaminan namun hampir tidak ada desa yang luput dari intervensi pemerintahan tingkat provinsi dan pusat, peluang untuk melakukan perubahan secara substansial di desa diharapkan melalui otonomi.

\section{SIMPULAN}

Mewujudkan demokrasi ditingkal lokal melalui otonomi daerah mencakup prinsip demokrasi, peran serta masyarakat, pemerataan dan keadilan serta potensi, dan keragaman daerah. Prinsip ini memberikan usaha dalam upaya membangun struktur dan mekanisme kerja sistem politik yang berdasarkan atas nilai-nilai dasar demokratis. Otonomi harus memberikan kesempatan peran serta masyarakat untuk berpartisipasi dalam pembangunan daerah, serta dapat memunculkan potensi daerahnya untuk digali demi keadilan dan pemerataan kesejahteraan.

Kebijakan otonomi daerah merupakan upaya pemberdayaan daerah, maka kepentingan daerah harus menjadi prioritas utama. Membudayakan Daerah menjadi prioritas setiap proyek pembangunan nasional, serta masyarakat menjadi terlibat secara aktif dalam setiap perencanaan hingga pelaksanaan, dan evaluasi 
kegiatan-kegiatan yang berhubungan dengan daerah sendiri, selain itu daerah diharapkan mampu melakukan terobosan-terobosan inovatif untuk mengembangkan dan mamajukan dirinya sendiri, sehingga daerahnya sebanding dan dapat sejajar dengan percaturan nasional dan internasional.

\section{REFERENSI}

Antlov, Hans, Negara dalam Desa, Patronase Kepemimpinan Lokal, Yogyakarta: Lappera Pustaka Utama, 2003.

Aziz, Abdul, dam David Arnold, Desentralisasi Pemerintahan Pengalaman Negara-negara Asia, Yogyakarta: Pustaka Amanah, 2003.

Bourchier, David, Pancasila Versi Orde Baru, Jakarta: Penerbit Pusat Studi Pancasila UGM bekerjasama dengan Pusat Studi Sosial Asia Tenggara UGM dan Perhimpunan Pendidikan Demokrasi, 2007.

Effendi, Sofian, Syafri, Ed, Membangun Martabat Manusia, Yogyakarta: Gadjah Mada University Press, 1986.

Gaffar, Afan, Politik Indonesia Transisi Menuju Demokrasi, Yogyakarta: Pustaka Pelajar Offset, 2006.

Haris, Syamsudin, Desentralisasi dan Otonomi Daerah, Jakarta: Penerbit LIPI Press, 2005.

Held, David, Demokrasi \& Tatanan Global, Yogyakarta: Pustaka Pelajar Offset, 2004.

Kaelan, Filsafat Pancasila, Yogyakarta: Penerbit Fakultas Filsafat Universitas Gadjah Mada, 1990.

Pendidikan Pancasila, Yogyakarta: Penerbit Pradigma, 2004.

Karim, Abuya Busyro, Indonesia Globalisasi Otonomi Daerah, Yogyakarta: Penerbit Pilar, 2005

MD, Mahfud, Moh, Dasar dan Struktur Ketatanegaraan Indonesia, Jakarta: Penerbit Rineka Cipta, 2001.

Mardiasmo, Otonomi \& Manajemen Keuangan Daerah, Yogyakarta: Andi, 2004.

Maulani, Demokrasi dan Pembangunan Daerah, Yogyakarta: CRDS Kalimantan Bekerja Sama Pustaka Pelajar, 2000.

Rawls, John, Teori Keadilan, Dasar-dasar Filsafat Politik untuk Mewujudkan Kesejahteraan Sosial dalam Negara, Yogyakarta: Pustaka Pelajar, 2006.

Ruhpina, Said, Menuju Demokrasi Pemerintahan, Mataram: Penerbit Universitas Mataram Perss, 2005.

Santoso, Edi, Demokrasi dalam Otonomi Daerah, Yogyakarta: Alief Press, 2004. 
Scmandt, Herry, J, Filsafat Politik, Yogyakarta: Pustaka Pelajar, 2002.

Soejadi, Pancasila Sebagai Sumber Tertib Hukum Indonesia, Yogyakarta:

Lukman Ofset, 1999.

Sumanang, Rasyid, Bung Hatta Mengabdi pada Cita-cita Pembangunan

Bangsa, Jakarta: Penerbit Panitia Peringatan Ulang Tahun Bung Hatta ke 70, 1972.

Sunoto, Filsafat Pancasila, Yogyakarta:Prasetya Pratama, 1992.

Swasono, Sri Edi, Muhammad Hatta Beberapa Pokok Pikiran, Jakarta:

Penerbit Yayasan Hatta, 1992.

Bung Hatta Bapak Kedaulatan Rakyat, Jakarta: Yayasan

Hatta, 2002.

Syaukani, Otonomi Daerah dalam Negara Keastuan, Yogyakart: Pustaka Pelajar, 2009. 
